AdAM MALIK ${ }^{1}$

\title{
Ocena ryzyk ubezpieczeniowych w obowiązkowym ubezpieczeniu upraw rolnych
}

Znaczenie rolnictwa jako sektora gospodarki przejawia się nie tylko w jego udziale w PKB oraz na rynku zatrudnienia, ${ }^{2}$ ale również w istotnym wpływie na bezpieczeństwo żywnościowe kraju, a także pośrednio na bezpieczeństwo energetyczne, zarządzanie zasobami naturalnymi, gospodarkę towarową, różnorodność fauny czy kształtowanie obszarów wiejskich. W związku z takim znaczeniem tego sektora, wszelkie anomalia związane z działalnością produkcyjną negatywnie wpływają na korelujące gałęzie gospodarki, jak również na poziom życia konsumentów dóbr wytwarzanych w rolnictwie. Z tego też względu, w ramach Wspólnej Polityki Rolnej UE na lata 2014-2020 ograniczono wprawdzie zakres publicznych interwencji rynkowych, jednakże na rzecz położenia nacisku na zarządzanie ryzykiem w gospodarstwach rolnych, ${ }^{3}$ dążąc przede wszystkim do ustabilizowania ich dochodów. Jednym z narzędzi pozwalających na osiągnięcie tego stanu jest system zarządzania ryzykiem ${ }^{4}$ na poziomie funkcjonujących $\mathrm{w}$ rolnictwie ubezpieczeń majątkowych

$1 \quad$ Uniwersytet Śląski.

2 Jak podaje GUS, w 2014 roku szeroko rozumiane rolnictwo odpowiadało za 3\% PKB (analogicznie w 2013 roku $3,24 \%$ oraz 2010 roku 2,91\%) oraz pozwoliło na zatrudnienie ok. 14,5\% pracowników (analogicznie w 2013 roku - 15,6\% oraz w 2010 roku - 15,5\%), [w:] Rocznik Statystyczny Rzeczypospolitej Polskiej 2015, Warszawa 2015, s. 244 i 706.

Jak wynika z art. 36-38 rozporządzenia Parlamentu Europejskiego i Rady (UE) nr 1305/2013 z dnia 17 grudnia 2013 r. w sprawie wsparcia rozwoju obszarów wiejskich przez Europejski Fundusz Rolny na rzecz Rozwoju Obszarów Wiejskich (EFRROW) oraz uchylającego rozporządzenie Rady (WE) nr 1698/2005 (Dz.U.UE.L.347 z dnia 20 grudnia 2013 r., s. 487), zarządzanie ryzykiem w ramach Wspólnej Polityki Rolnej w latach 20142020 może dotyczyć: 1) dofinansowania składek ubezpieczenia upraw, zwierząt i roślin od ponoszonych przez rolników strat gospodarczych spowodowanych niekorzystnymi zjawiskami klimatycznymi, chorobami zwierząt lub roślin, inwazją szkodników lub incydentem środowiskowym; 2) dofinansowania kosztów administracyjnych utworzenia funduszu wspólnego inwestowania (maksymalnie przez 3 lata) oraz refundacji wypłacanych rolnikom z funduszu rekompensat finansowych w związku ze stratami spowodowanymi niekorzystnymi zjawiskami klimatycznymi, chorobami zwierząt lub roślin, inwazją szkodników lub incydentem środowiskowym, a nadto refundacji odsetek od pożyczek zaciągniętych przez fundusz na wypłatę rekompensat; 3) wkładów finansowych na rzecz funduszu wspólnego inwestowania, na pokrycie rekompensat z tytułu spadku dochodów przekraczającego $30 \%$ średniego dochodu indywidualnego rolnika.

4 Jak wskazuje M. Serwach, [w:] Ryzyko ubezpieczeniowe, Wybrane zagadnienia teorii i praktyki, M. Serwach (red.), Łódź 2013, s. 13, ryzyko ujmowane w kategoriach ekonomicznych i prawnych określane jest jako niepewność zaistnienia zagrożenia, któremu można przypisać prawdopodobieństwo wystąpienia pewnego zdarzenia, wystąpienia określonej straty. Zarządzanie ryzykiem polega przy tym na podejmowaniu działań zarządczych, których zadaniem jest ocena ryzyka, walka z jego przyczynami oraz wpływem ewentualnego ziszczenia się ryzyka na organizację działania. Działania te polegają przy tym nie tylko na identyfikacji ryzyka, ale również na anali- 
(zarówno obligatoryjnych, jak również fakultatywnych), które stwarzając możliwość uniknięcia niekorzystnych dla branży rolniczej skutków zdarzeń losowych, przekładają się wprost na sytuację majątkową podmiotów tego sektora gospodarki, a pośrednio również na gałęzie gospodarki, na które sytuacja ekonomiczna rolnictwa oddziałuje.

Niniejsza publikacja stanowi próbę dokonania analizy zakresu obowiązującego w RP przymusowego ${ }^{5}$ ubezpieczenia upraw rolnych, z punktu widzenia poszczególnych ryzyk (wypadków) ubezpieczeniowych.

\section{Rys historyczny obligatoryjnych ubezpieczeń upraw na obszarze RP}

W odrodzonej Polsce, na mocy art. 3 ust. 1 i 2 rozporządzenia Prezydenta RP z dnia 27 maja 1927 r. o przymusie ubezpieczenia od ognia i o Powszechnym Zakładzie Ubezpieczeń wzajemnych, ${ }^{6}$ wprowadzono możliwość ustanawiania przez sejmiki wojewódzkie przymusu ubezpieczenia plonów od gradobicia, pod warunkiem objęcia nim obszaru całego województwa. W oparciu o przedmiotowe rozporządzenie, obowiązkiem ubezpieczeniowym objęto zboże w ziarnie, słomę i paszę oraz rośliny techniczne: len, tytoń i chmiel. Z obowiązku ubezpieczeniowego wyłączono natomiast okopowizny, ziemiopłody na pniu, poślady, zgoniny, plewy, słomę roślin oleistych, jak również nawóz.

Tak wprowadzony obowiązek ubezpieczeniowy zmieniono rozporządzeniem Rady Ministrów z dnia 24 listopada 1956 r., ${ }^{7}$ rozszerzając zakres ubezpieczenia o skutki powodzi, jednakże ograniczając przedmiot ubezpieczenia do żyta, pszenicy, jęczmienia, owsa oraz kukurydzy. Zakres ten rozszerzono kolejnymi rozpo-

zowaniu możliwości wyboru odpowiedniej metody obchodzenia się z ryzykiem oraz wdrażania programu pozwalającego na jego zniwelowanie lub choćby ograniczenie.

$5 \quad$ Faktycznie na gruncie ubezpieczenia upraw rolnych powinno mówić się o przymusowym, a nie obowiązkowym ubezpieczeniu. Wprawdzie ustawodawca w art. 10c ustawy z dnia 7 lipca 2005 r. o ubezpieczeniach upraw i zwierząt gospodarskich (tekst jedn. Dz.U. z 2016 r., poz. 792) posługuje się zwrotem „ubezpieczenie obowiązkowe", to jednak mając na względzie regulację systemową - art. 4 pkt 1-4 oraz art. 11 ust. 1 ustawy z dnia 22 maja 2003 r. o ubezpieczeniach obowiązkowych, Ubezpieczeniowym Funduszu Gwarancyjnym i Polskim Biurze Ubezpieczycieli Komunikacyjnych (tekst jedn.: Dz.U. z 2013 r., poz. 392 ze zm.), która na gruncie ubezpieczeń upraw znajduje zastosowanie wyłącznie do kontroli spełniania obowiązku ubezpieczenia oraz dochodzenia opłat za niespełnienie tego obowiązku, uznać należy, że ubezpieczenie upraw stanowi najwyżej ubezpieczenie obowiązkowe sensu largo. W tej materii doktryna postuluje posługiwanie się pojęciem ubezpieczeń przymusowych, dla podkreślenia odrębności ubezpieczeń regulowanych innymi aktami prawnymi niż ustawa o ubezpieczeniach obowiązkowych. Szerzej na ten temat: M. Orlicki, Ubezpieczenia Obowiązkowe, Warszawa 2011, s. 172.

Dz.U. R.P. nr 46, poz. 410. W oparciu o delegację z art. 74 rozporządzenia, Ministra Skarbu rozporządzeniem z dnia 31 stycznia 1929 r. w sprawie przymusu ubezpieczenia od ognia ruchomości w gospodarstwach rolnych, przymusu ubezpieczenia żywego inwentarza od wypadków śmierci oraz przymusu ubezpieczenia plonów od gradobicia (Dz.U. R. P. nr 113 poz. 112) ustalił szczegółowe zasady obejmowania upraw obowiązkiem ubezpieczeniowym.

7 Rozporządzenie w sprawie obowiązkowego ubezpieczenia ziemiopłodów od gradobicia i powodzi (Dz.U. z 1956 r., nr 57, poz. 262). 
rządzeniami Rady Ministrów o proso, grykę i ziemniaki (1963 r.), ${ }^{8}$ a także rośliny pastewne i okopowe (uprawiane na paszę), buraki cukrowe oraz łąki i pastwiska (1972 r.). ${ }^{9}$ W następnych latach (1974 r., ${ }^{10} 1982$ r., ${ }^{11} 1985$ r., ${ }^{12} 1989$ r. $\left.{ }^{13}\right)$, kolejne rozporządzenia Rady Ministrów w kontekście ubezpieczeń upraw skupiały się głównie na doprecyzowaniu przedmiotu ubezpieczenia jako elementów poszczególnych upraw objętych ochroną ubezpieczeniową, a także modyfikowaniu zasad ustalania zakresu szkody oraz wypłaty należnego odszkodowania. Warto przy tym odnotować rozszerzenie (w rozporządzeniu z 1985 roku) zakresu ryzyk ubezpieczeniowych o skutki działania ognia i zalania wskutek nadmiernych opadów atmosferycznych (co zostało utrzymane w rozporządzeniu z 1989 roku).

Ostatecznie, obowiązkowe ubezpieczenia upraw zostały uchylone z dniem 28 sierpnia 1990 r., tj. datą wejście w życie ustawy o działalności ubezpieczeniowej. ${ }^{14}$ Przymus ubezpieczeniowy w zakresie upraw rolnych wprowadzono ponownie ustawą z dnia 7 marca 2007 r. o zmianie ustawy o dopłatach do ubezpieczeń upraw rolnych i zwierząt gospodarskich oraz niektórych innych ustaw, ${ }^{15}$ która nowelizując ustawę z dnia 7 lipca 2005 r. o dopłatach do ubezpieczeń upraw rolnych i zwierząt gospodarskich, ${ }^{16}$ zmieniła jej tytuł, ustanawiając również obligatoryjne ubezpieczenie upraw rolnych. ${ }^{17} \mathrm{Nie}$ jest to jednak przymus powszechny, w przeciwieństwie wcześniej obowiązujących w tym zakresie regulacji, o czym będzie mowa w dalszej części niniejszego opracowania.

\section{Obowiązek ubezpieczenia upraw rolnych - przesłanki}

Rodzimy ustawodawca ustanawiając przymus kontraktowy ubezpieczenia upraw rolnych odniósł go zasadniczo do wszystkich aspektów tego obowiązku, poczynając od jego zakresu podmiotowego oraz przedmiotowego, kończąc na regulacjach dotyczących ustalania rozmiarów uszczerbku podlegającego naprawieniu

Rozporządzenie Rady Ministrów z dnia 14 czerwca 1963 r. w sprawie obowiązkowego ubezpieczenia ziemiopłodów od gradobicia i powodzi (Dz.U. z 1963 r., nr 31, poz. 176).

Rozporządzenie Rady Ministrów z dnia 1 lutego 1972 r. w sprawie obowiązkowego ubezpieczenia ziemiopłodów od gradobicia i powodzi (Dz.U. z 1972 r., nr 5, poz. 25). Na mocy przedmiotowego rozporządzenia, ziemniaki, rośliny pastewne i okopowe, buraki cukrowe oraz łąki i pastwiska podlegały ubezpieczeniu wyłącznie od skutków powodzi.

10 Rozporządzenie Rady Ministrów z dnia 20 grudnia 1974 r. w sprawie obowiązkowych ubezpieczeń budynków oraz mienia w gospodarstwach rolnych (Dz.U. z 1974 r., nr 49, poz. 303).

11 Rozporządzenie Rady Ministrów z dnia 15 listopada 1982 r. w sprawie obowiązkowego ubezpieczenia budynków oraz mienia w gospodarstwach rolnych (Dz.U. z 1982 r., nr 38, poz. 250).

12 Rozporządzenie Rady Ministrów z dnia 21 lutego 1985 r. w sprawie ubezpieczenia ustawowego budynków oraz mienia w gospodarstwach rolnych (Dz.U. z 1985 r., nr 10, poz. 38).

13 Rozporządzenie Rady Ministrów z dnia 5 grudnia 1989 r. w sprawie ubezpieczenia ustawowego budynków i mienia w gospodarstwach rolnych oraz na działkach nie wchodzących w skład gospodarstw rolnych (Dz.U. z 1989 r., nr 68, poz. 412).

14 Ustawa z dnia 28 lipca 1990 r. o działalności ubezpieczeniowej (Dz.U. z 1990 r., nr 59, poz. 334 ze zm.).

15 Dz.U. z 2007 r., nr 49, poz. 328.

16 Dz.U. z 2005 r., nr 150, poz. 1249.

17 Tekst jedn.: Dz.U. z 2016 r., poz. 792, dalej zwana: u.u.r. 
w ramach tego ubezpieczenia oraz wysokości należnego świadczenia odszkodowawczego. Obowiązek zawarcia umowy ubezpieczenia upraw uzależniony jest przy tym od spełnienia wprowadzanych $\mathrm{w}$ art. 10c ust. 1 u.u.r. trzech zasadniczych warunków, tj. posiadania statusu rolnika, uzyskania płatności bezpośrednich na podstawie systemów wsparcia bezpośredniego, a także prowadzenia określonej działalności rolniczej.

Tak wprowadzona regulacja nawiązuje do nieobowiązującego aktualnie na szczeblu unijnym obowiązku ,posiadania polis ubezpieczenia 50\% upraw przez rolników, którzy od $2010 \mathrm{r}$. będą ubiegać się o inne formy wsparcia z budżetu w przypadku wystąpienia klęsk." ${ }^{18}$ Rozwiązanie to podyktowane było art. 11 ust. 8 rozporządzenia Komisji (WE) nr 1857/2006, ${ }^{19}$ zgodnie z którym od dnia 1 stycznia 2010 r. zaoferowane przez państwo członkowskie odszkodowanie (udzielone w ramach pomocy na rzecz strat spowodowanych niektórymi zjawiskami klimatycznymi) musiało być zmniejszone o 50\%, chyba że przyznawane było rolnikom, którzy dokonali ubezpieczenia pokrywającego co najmniej $50 \%$ średniej rocznej produkcji lub dochodu związanego z produkcją i obejmującego zagrożenia związane z niekorzystnymi zjawiskami klimatycznymi statystycznie najczęściej występującymi w danym państwie członkowskim lub regionie. Przedmiotowa regulacja faktycznie zrywając $\mathrm{z}$ ograniczeniem $\mathrm{w}$ przyznawaniu pomocy poszkodowanym rolnikom stanowić mogła (obowiązywała do końca $2013 \mathrm{r}^{20}$ ) z jednej strony narzędzie uzupełnienia wypłaconego świadczenia odszkodowawczego, w zakresie w jakim po stronie rolnika utrzymywały się straty spowodowane zjawiskami klimatycznymi, a dodatkowo zezwalała na przyznanie pełnego odszkodowania w przypadku wyrządzenia rolnikowi szkody nieobjętej zakresem udzielanej ochrony ubezpieczeniowej (byle tylko zakres ryzyk ubezpieczeniowych odpowiadał zjawiskom statystycznie najczęściej występującym w danym państwie członkowskim lub regionie).

Regulacje ustawy o ubezpieczeniach upraw rolnych i zwierząt gospodarskich, wywierają wpływ także na umowy dobrowolnego ubezpieczenia upraw, w zakresie w jakim strony stosunku ubezpieczeniowego zainteresowane są uzyskaniem wypłacanych przez Skarb Państwa dopłat do składek ubezpieczeniowych (art. 3 ust. 1 u.u.r.) oraz dotacji na pokrycie części odszkodowań wypłaconych producentom rolnym z tytułu szkód spowodowanych przez suszę (art. 10a ust. 1 u.u.r.). W tym kontekście należy zwrócić uwagę na to, że normy przedmiotowej ustawy określają treść umowy ubezpieczenia w sposób ramowy oraz selektywny. W rezultacie, treść sto-

18 Uzasadnienie projektu ustawy o zmianie ustawy o ubezpieczeniach upraw rolnych i zwierząt gospodarskich oraz niektórych innych ustaw, druk sejmowy nr 1315 z dnia 12 stycznia $2007 \mathrm{r}$.

19 Rozporządzenie z dnia 15 grudnia 2006 r. w sprawie stosowania art. 87 i 88 Traktatu w odniesieniu do pomocy państwa dla małych i średnich przedsiębiorstw prowadzących działalność związaną z wytwarzaniem produktów rolnych oraz zmieniające rozporządzenie (WE) nr 70/2001 (Dz.Urz. UE L 358 z dnia 16 grudnia 2006 r., s. 3). Na mocy rozporządzenia Komisji (UE) nr 1114/2013 z dnia 7 listopada 2013 r. zmieniające rozporządzenie (WE) nr 1857/2006 w odniesieniu do okresu jego stosowania (Dz.Urz. UE L 298 z dnia 8 listopada 2013 r., s. 34), rozporządzenie $\mathrm{nr}$ 1857/2006 utraciło moc z dniem 31 grudnia $2013 \mathrm{r}$. 
sunku prawnego ubezpieczenia (zarówno dobrowolnego, jak również przymusowego) w zakresie nieuregulowanym ustawą (a także bezwzględnymi regulacjami zawartymi w art. 805 k.c. - art. 827 k.c.) zależy od woli stron stosunku prawnego ubezpieczenia. Wskazuje na to pośrednio art. 9 ust. 1 u.u.r. w zw. z art. 9 ust. 4 pkt 4 i 10 u.u.r., wprowadzając jako jedne z elementów składanej przez zakład ubezpieczeń ministrowi właściwemu do spraw rolnictwa oferty umowy w sprawie dopłat, warunki ubezpieczenia upraw oraz warunki likwidacji szkód. Podobny wniosek wynika zresztą z art. 10c ust. 3 u.u.r. w zakresie, w jakim rolnikowi pozostawiono swobodę wyboru zakładu ubezpieczeń, także w odniesieniu do zakładów, które nie zawarły w ministrem właściwym do spraw rolnictwa umowy w sprawie dopłat. Aprobująco w tym przedmiocie wypowiada się również doktryna, ${ }^{21}$ a w praktyce podobne rozwiązania występują powszechnie. ${ }^{22}$

Ustawodawca wprowadzając po stronie rolnika obowiązek zawarcia umowy ubezpieczenia nie definiuje jednocześnie pojęcia „rolnik”, odsyłając w tym zakresie do definicji z art. 4 ust. 1 lit. a rozporządzenia Parlamentu Europejskiego i Rady (UE) nr 1307/2013 z dnia 17 grudnia 2013 r. ustanawiającego przepisy dotyczące płatności bezpośrednich dla rolników na podstawie systemów wsparcia w ramach wspólnej polityki rolnej oraz uchylającego rozporządzenie Rady (WE) nr 637/2008 i rozporządzenie Rady (WE) nr 73/2009. ${ }^{23}$

Zgodnie art. 4 ust. 1 lit. a tego rozporządzenia, pod pojęciem „rolnik” rozumie się osobę fizyczną lub prawną bądź grupę osób fizycznych lub prawnych, bez względu na status prawny takiej grupy i jej członków w świetle prawa krajowego, których gospodarstwo rolne jest położone na obszarze objętym zakresem terytorialnym traktatów, które prowadzą działalność rolniczą. Co istotne, tak skonstruowana definicja stosowana jest w ustawie wyłącznie dla określenia zakresu podmiotowego obowiązku ubezpieczeniowego. W pozostałych przypadkach ustawodawca posługuje się pojęciem ,producent rolny” (art. 2 pkt 2 u.u.r.), nawiązując do rozporządzenia nr 1307/2013 wyłącznie w zakresie definicji działalności rolniczej. Wspólnym mianownikiem obu pojęć pozostaje przez to wyłącznie fakt dysponowania gospodarstwem rolnym, choć i w tym zakresie oba pojęcia się różnią, przesądzając o szerszym zakresie definicji ,rolnik” wprowadzonej w rozporządzeniu nr 1307/2013. Podobnie zresztą jak w przypadku pojęcia ,rolnika”, ustawodawca postępuje w od-

21 J. Nawracała, [w:] Prawo ubezpieczeń gospodarczych. Komentarz, t. I, Z. Brodecki, M. Serwach, M. Glicz (red.), Warszawa 2010, s. 1274.

22 Wspólne ogólne warunki ubezpieczenia upraw dla umów przymusowego oraz dobrowolnego ubezpieczenia wprowadziły m.in. PZU S.A. - ogólne warunki ubezpieczenia PZU uprawy ustalone uchwałą nr UZ/320/2014 r. Zarządu Powszechnego Zakładu Ubezpieczeń S.A. z dnia 12 listopada 2014 r.; TUW - ogólne warunki ubezpieczenia upraw rolnych i zwierząt gospodarskich od zdarzeń losowych, realizowanego w ramach umowy zawartej z Ministrem Rolnictwa i Rozwoju Wsi w sprawie dopłat udzielanych na podstawie ustawy o ubezpieczeniach upraw rolnych i zwierząt gospodarskich; Concordia TU S.A. - ogólne warunki ubezpieczenia upraw rolnych nr UPR/OWU/16/04. Dz.Urz. UE L 347 z dnia 20 grudnia 2013 r., s. 608, dalej zwane rozporządzeniem nr 1307/2013. 
niesieniu do definicji gospodarstwo rolne (art. 2 pkt 1 u.u.r.). Rodzima regulacja w tym zakresie nie znajduje zastosowania do ubezpieczeń obligatoryjnych, o czym wprost stanowi odwołanie w art. 10c ust. 1 u.u.r. do rolników w rozumieniu rozporządzenia 1307/2013. W świetle natomiast treści unijnej definicji rolnik, nie sposób określić jej zakresu bez odniesienia się do wprowadzanego w art. 4 ust. 2 rozporządzenia nr 1307/2013 pojęcia gospodarstwo rolne. ${ }^{24}$ Skądinąd zwrócić w tym miejscu należy uwagę na to, że to właśnie definicja gospodarstwa rolnego wprowadza zasadniczy rozdźwięk pomiędzy pojęciami rolnik (w rozumieniu rozporządzenia 1307/2013) oraz producent rolny (art. 2 pkt 2 u.u.r.), a różnica w tym zakresie sprowadza się przede wszystkim do skupienia się przez ustawodawcę unijnego na funkcjonalnym aspekcie tego pojęcia, podczas gdy rodzimy ustawodawca ujmuje je w rozumieniu przepisów podatkowych (podobnie zresztą czyni w pozostałych obowiązkowych ubezpieczeniach rolnych), odnosząc się przede wszystkim do klasyfikacji gruntów wchodzących w skład gospodarstwa rolnego (art. 2 ust. 1 w zw. $\mathrm{z}$ art. 1 ustawy z dnia 15 listopada 1984 r. o podatku rolnym; ${ }^{25}$ art. 2 ust. 3 ustawy z dnia 26 lipca 1991 r. o podatku dochodowym od osób fizycznych ${ }^{26}$ ).

Wreszcie, elementem definicji pojęcia rolnik w rozumieniu art. 4 ust. 1 lit. a rozporządzenia Rady (WE) nr 637/2008 jest prowadzenie działalności rolniczej, rozumianej jako produkcja, hodowla lub uprawa produktów rolnych, włączając w to zbiory, dojenie, chów zwierząt oraz utrzymywanie zwierząt dla celów gospodarczych lub utrzymywanie gruntów w dobrej kulturze rolnej zgodnej z ochroną środowiska. Działalność, która nie odpowiada zakresowi tej definicji będzie przesądzała o braku powstania przymusu ubezpieczeniowego.

Jak wynika z art. 10c ust. 1 u.u.r. obowiązek ubezpieczeniowy wynika wprost z uzyskania przez rolnika płatności bezpośrednich w rozumieniu przepisów o płatnościach $\mathrm{w}$ ramach systemu wsparcia bezpośredniego. W tym kontekście należy przede wszystkim zwrócić uwagę na regulację ustawy z dnia 5 lutego 2015 r. o płatnościach $\mathrm{w}$ ramach systemu wsparcia bezpośredniego ${ }^{27}$ oraz przepisy unijne wprowadzające następujące rodzaje płatności: jednolita płatność obszarowa (art. 36 ust. 2 rozporządzenia nr 1307/2013); płatność za zazielenienie (tytuł III, rozdział 3 rozporządzenia nr 1307/2013); płatność dla młodych rolników (tytuł III, rozdział 5 rozporządzenia nr 1307/2013); płatność dodatkowa (tytuł III, rozdział 2 rozporządzenia nr 1307/2013); płatność w ramach systemu dla małych gospodarstw (art. 61 rozporządzenia nr 1307/2013); przyznawane w sektorach produkcji roślinnej płatności związane do powierzchni upraw w ramach dobrowolnego wsparcia związanego z produkcją (tytuł IV, rozdział 1 rozporządzenia nr 1307/2013); przyznawane

Pod pojęciem tym rozumie się wszystkie jednostki wykorzystywane do działalności rolniczej i zarządzane przez rolnika, znajdujące się na terytorium tego samego państwa członkowskiego.

Tekst jedn. Dz.U. z 2015 r., poz. 1551. 
w sektorach produkcji zwierzęcej płatności związane do zwierząt w ramach dobrowolnego wsparcia związanego z produkcją (tytuł IV, rozdział 1 rozporządzenia nr 1307/2013).

Zgodnie z treścią art. 10c ust. 1 u.u.r., powinność ubezpieczeniowa posiada charakter następczy w stosunku do uzyskanych płatności bezpośrednich. $\mathrm{Z}$ tego też względu, ewentualny późniejszy obowiązek zwrotu płatności, czy też uzyskanie ich w szerszym zakresie nie wpływa na powstały wcześniej obowiązek ubezpieczeniowy. Nie wiadomo przy tym, czy dla powstania obowiązku ubezpieczeniowego wystarcza uprawomocnienie decyzji w przedmiocie przyznania płatności (art. 24 ustawy o płatnościach w ramach systemu wsparcia bezpośredniego), czy też konieczne jest w tym zakresie ziszczenie się czynności faktycznej polegającej na wypłacie przyznanej rolnikowi płatności (ustawodawca tego nie rozstrzyga). Wydaje się przy tym, że powstanie prawa do płatności wynikające z uprawomocnienia decyzji administracyjnej, a w rezultacie powstanie roszczenia o jej wypłatę stanowi wystarczającą przesłankę do postawienia tezy o wykreowaniu się obowiązku zawarcia umowy ubezpieczenia upraw.

Trzecią przesłanką, której wystąpienie prowadzi do powstania obowiązku ubezpieczeniowego jest prowadzenie działalności rolniczej zorientowanej na uprawę zbóż, kukurydzy, rzepaku, rzepiku, chmielu, tytoniu, warzyw gruntowych, drzew i krzewów owocowych, truskawek, ziemniaków, buraków cukrowych lub roślin strączkowych. Tak wprowadzony zakres przedmiotowy obowiązku ubezpieczonego wynika wprost $\mathrm{z}$ art. $10 \mathrm{c}$ ust. 1 in fine u.u.r. $\mathrm{Z}$ normy tej wynika również możliwość modyfikacji obowiązku ubezpieczeniowego przez samego rolnika. Skoro bowiem obowiązek ten powstaje na przyszłość - w stosunku do roku kalendarzowego, w którym rolnik otrzymał płatności bezpośrednie, to podejmując decyzję o przedmiocie produkcji rolnej w kolejnym roku, jednocześnie decyduje o zakresie obciążającego go obowiązku ubezpieczeniowego, czy też jego wyłączeniu (w przypadku rezygnacji z produkcji upraw podlegających obowiązkowi ubezpieczenia).

\section{Przedmiot i zakres ubezpieczenia w obligatoryjnym ubezpieczeniu upraw}

Aby spełnić ustawowy obowiązek zawarcia umowy ubezpieczenia, od 1 lipca roku następującego po roku, za który rolnik uzyskał płatności bezpośrednie, w okresie 12 miesięcy ochroną ubezpieczeniową musi zostać objęte co najmniej 50\% powierzchni upraw, o których mowa w art. 3 ust. 1 u.u.r. (zboże, kukurydza, rzepak, rzepik, chmiel, tytoń, warzywa gruntowe, drzewa i krzewy owocowe, truskawki, ziemniaki, buraki cukrowe oraz rośliny strączkowe), od szkód spowodowanych przez co najmniej jedno z ryzyk ubezpieczeniowych, o których mowa w art. 10c ust. 1 in fine u.u.r., tj. powodzi, suszy, gradu, ujemnych skutków przezimowania 
lub przymrozków wiosennych. ${ }^{28}$ Co istotne, umowa ubezpieczenia może obejmować wyłącznie plon główny roślin podlegających ubezpieczeniu. ${ }^{29}$ Konieczne jest również zwrócenie uwagi na to, że przymusowe ubezpieczenie upraw obejmuje jedynie część z szerokiego zakresu dopuszczalnych ryzyk ubezpieczeniowych regulowanych oraz definiowanych przez przedmiotową ustawę, na które składają się dodatkowo: huragan, deszcz nawalny, piorun, obsunięcie się ziemi oraz lawina. Wyraźnie jednak ustawodawca zaakcentował fakt, że objęcie ochroną ubezpieczeniową plonów od tych ryzyk możliwe jest wyłącznie na podstawie umowy dobrowolnego ubezpieczenia upraw - zawartej odrębnie od umowy obligatoryjnego ubezpieczenia, bądź z odpowiednio szerszym zakresem ubezpieczenia (art. 10c ust. 10 u.u.r. w zw. $\mathrm{z}$ art. 3 ust. 1a u.u.r.).

Ryzyko, o którym mowa w art. 10c ust. 1 u.u.r. nierozerwalnie związane jest z zagadnieniem wystąpienia określonego zdarzenia losowego, pod którym to pojęciem ustawodawca w art. 3 ust. 1 pkt 57 ustawy z dnia 11 września 2015 r. o działalności ubezpieczeniowej i reasekuracyjnej ${ }^{30}$ rozumie niezależne od woli ubezpieczającego lub ubezpieczonego zdarzenie przyszłe i niepewne, którego wystapienie powoduje uszczerbek w dobrach osobistych lub w dobrach majątkowych albo zwiększenie potrzeb majątkowych po stronie ubezpieczającego lub innej osoby objętej ochroną ubezpieczeniową. Istotą wypadku ubezpieczeniowego jest zatem przewidziane w umowie ubezpieczenia zdarzenie losowe, z którego nastąpieniem ekspektatywa ubezpieczającego, mająca za przedmiot spodziewane świadczenie pieniężne od zakładu ubezpieczeń, przeradza się w wierzytelność ubezpieczeniową, czyli skonkretyzowane prawo podmiotowe o charakterze majątkowym". ${ }^{31}$ Jako wskazuje A. Wąsiewicz, pod pojęciem wypadek ubezpieczeniowy rozumie się zdarzenie losowe, które objęte jest działalnością ubezpieczeniową oraz z którego nastąpieniem zakład ubezpieczeń staje się, w myśl postanowień warunków danego stosunku prawnego ubezpieczenia, obowiązany spełnić świadczenie ubezpieczeniowe. ${ }^{32} \mathrm{Ma}-$ jąc to na uwadze, należy stwierdzić, że wystąpienie zdarzenia losowego, określone-

Jak wskazano w uzasadnieniu projektu z dnia 25 kwietnia 2016 r. ustawy o zmianie ustawy o ubezpieczeniu upraw rolnych i zwierząt gospodarskich (druk sejmowy nr VIII.469), z danych przedkładanych przez zakłady ubezpieczeń, które zawarły umowy w sprawie dopłat do składek ubezpieczeń upraw wynika, że umowy obejmujące ryzyka powodzi, suszy, gradu, przymrozków wiosennych oraz ujemnych skutków przezimowania obejmują najczęściej jeden tylko rodzaj ryzyka. Wynika z tego, że w praktyce ścisłe wypełnianie obowiązku ubezpieczeniowego przeważa nad potrzebą szerokiego zarządzania ryzykiem prowadzonej działalności rolniczej w zakresie upraw oraz oferowanymi przez zakłady ubezpieczeń pakietami ubezpieczeniowymi w zakresie ubezpieczenia upraw.

Za plon główny, art. 3 ust. 3 ustawy uznaje się: korzenie buraka (buraki cukrowe); kolby i nadziemne części rośliny (kukurydza przeznaczona na paszę); ziarna lub nasiona (zboże, rzepak i rzepik, kukurydza przeznaczona na ziarno); bulwy (ziemniaki); części warzyw przeznaczone do konsumpcji (warzywa gruntowe); owoce lub całe nasadzenia (drzewa i krzewy owocowe oraz truskawki); szyszki (chmiel); liście (tytoń); nasiona (rośliny strączkowe).

30 Dz.U. z 2015 r., poz. 1844.

31 E. Kowalewski, Prawo ubezpieczeń gospodarczych, Bydgoszcz - Toruń 2002, s. 104.

32 A. Wąsiewicz, Umowa ubezpieczenia, [w:] A. Wąsiewicz (red.), Ubezpieczenia w gospodarce rynkowej t. 3, Bydgoszcz 1997, s. 105. 
go na gruncie art. $805 \S 1$ k.c. oraz. art. 10c ust. 1 u.u.r. mianem wypadku (ubezpieczeniowego), niesie za sobą konsekwencje w postaci uszczerbku - pojęcia, które na tle ubezpieczeń majątkowych zawiera w sobie desygnat w postaci szkody majątkowej. ${ }^{33}$ Oznacza to, że z ochroną ubezpieczeniową mamy do czynienia wówczas, gdy dana umowa ubezpieczenia kreuje po stronie ubezpieczyciela obowiązek spełnienia świadczenia ochronnego w postaci odszkodowania ubezpieczeniowego, które materializuje się w razie wystąpienia szkody w uprawach stanowiących przedmiot ubezpieczenia, na skutek jednego ze zdarzeń określonych w umowie ubezpieczenia (zbieżnych - w odniesieniu do przymusowego ubezpieczenia upraw - z zakresem określonym w art. 10c ust. 1 in fine u.u.r.).

Definicje kolejnych ryzyk ubezpieczeniowych w ubezpieczeniach upraw ustawodawca wprowadza w art. 3 ust. 2 u.u.r. Wynika z tego, że aby móc stwierdzić spełnienie przez rolnika obowiązku ubezpieczeniowego na gruncie rzeczonej ustawy, przynajmniej jedno ze zdarzeń losowych musi być definiowane tak samo jak w przedmiotowej ustawie, bądź w sposób szerszy. Możliwe jest bowiem odstąpienie od regulacji poszczególnych definicji ryzyk, jednakże wyłącznie na korzyść ubezpieczającego, ubezpieczonego lub uprawnionego z umowy ubezpieczenia. Taki stan w świetle ustawy pojmowany będzie jednak jako rozszerzenie (na zasadzie dobrowolności) zakresu ochrony ubezpieczeniowej, obojętne dla przymusu ubezpieczeniowego wprowadzanego przez art. 10c ust. 1 u.u.r.

Zakres definicji pojęcia powódź (art. 3 ust. 2 pkt 3 u.u.r.) jest szerszy od tożsamego pojęcia wprowadzonego w regulacji odnoszącej się do obowiązkowego ubezpieczenia budynków wchodzących w skład gospodarstwa rolnego (art. 67 ust. 2 pkt 3 u.u.o.). Poza szkodami powstałymi wskutek zalania terenów w następstwie podniesienia się poziomu wód płynących lub stojących (zakres wspólny), w przypadku ubezpieczenia upraw przewidziano również uszczerbki powstałe na skutek zalania terenów przez deszcz nawalny (w rezultacie, przedmiotowe ryzyko nie obejmuje szkód powstałych w związku z siłami oddziałującymi na uprawy podczas deszczu nawalnego, co jest charakterystyczne dla przedmiotowej definicji ${ }^{34}$ ) oraz spływu wód po zboczach lub stokach na terenach górskich i podgórskich. Ustawodawca nie zdecydował się przy tym na zdefiniowanie w omawianym akcie prawnym pojęć tereny górskie oraz podgórskie. ${ }^{35}$ czych. Uwagi na tle art. 826 k.c., „Prawo Asekuracyjne” 2004, nr 2, s. 37 i n. Art. 3 ust. 2 pkt 4 u.u.r. pod pojęciem deszcz nawalny rozumie deszcz o współczynniku wydajności o wartości co
najmniej 4, a w przypadku braku możliwości ustalenia tego współczynnika, bierze się pod uwagę stan faktyczny oraz rozmiar szkód w miejscu ich powstania, świadczące wyraźnie o działaniach deszczu nawalnego. Pomocniczy może tu być art. 13b ust. 2 ustawy z dnia 15 listopada 1984 r. o podatku rolnym (tekst jen.: Dz.U. z 2016 r., poz. 617), za miejscowości położone na terenach podgórskich i górskich uważa się miejscowości, w których co najmniej 50\% użytków rolnych jest położonych powyżej 350 m.n.p.m. Podmiotem obowiązanym do sporządzenia wykazu takich miejscowości jest odpowiedni sejmik województwa. 
Ustawodawca definiując pojęcie powódź wypowiedział się również co do przyczyny powodzi jako ryzyka ubezpieczeniowego (skutki podniesienia poziomu wód, deszczu nawalnego oraz spływu wody po zboczach lub stokach). Obojętny dla ewentualnej odpowiedzialności zakładu ubezpieczeń z tego tytułu jest czynnik sprawczy tych zdarzeń. $\mathrm{Z}$ orzecznictwa wynika przy tym, że szkodami wyrządzonymi przez powódź są szkody powstałe na terenach, które chociażby na krótki czas zostały pokryte wodą ${ }^{36}$ Wreszcie, jak wskazuje Sąd Najwyższy, za powódź należy uważać nie tylko bezpośredni wylew wód bieżących lub stojących z ich naturalnych lub sztucznych łożysk, ale także wylew innych wód, nie wyłączając rowów i przegonów, jeżeli nastąpił on w wyniku akcji przeciwpowodziowej, na skutek zamknięcia śluz wałowych, zapobiegającego wprawdzie wylewowi głównego zbiornika wodnego, ale powodującego za to wylew wód z przyległej zlewni, pozbawionych na skutek zamknięcia śluz odpływu do głównego zbiornika. ${ }^{37}$ Orzecznictwo, podobnie jak ustawodawca, do przesłanki powodzi (jako zdarzenia ubezpieczeniowego) podchodzi zatem w sposób szeroki, skupiając się przede wszystkim na wystąpieniu oraz skutkach tego zdarzenia, a nie jego pierwotnych przyczynach.

W piśmiennictwie wskazuje się, że powódź nie powoduje znaczących strat w portfelach ubezpieczeń upraw, przede wszystkim ze względu na znikomą - systematycznie zmniejszającą się liczbę umów ubezpieczenia obejmujących to ryzyko ubezpieczeniowe. ${ }^{38} \mathrm{O}$ ile w 2010 roku zawarto lącznie 2.064 umowy ubezpieczenia obejmujących ryzyko powodzi, wypłacając z tego tytułu odszkodowania w kwocie łącznie 4.362.625,00 zł, to w 2015 roku umów tych było już 321, a suma wypłaconych z tego tytułu odszkodowań wyniosła $415.385,00$ zł. $^{39}$

Ryzyko „suszy” (art. 3 ust. 2 pkt 10 u.u.r.) definiuje się jako wystąpienie, w dowolnym sześciodekadowym okresie od dnia 1 kwietnia do dnia 30 września spadku klimatycznego bilansu wodnego poniżej wartości określonej dla poszczególnych gatunków roślin uprawnych i gleb. W literaturze wskazuje się na nieprecyzyjność przedmiotowej definicji, wskazując, że nie uwzględnia ona indywidualnego zapotrzebowania na wodę poszczególnych roślin uprawnych, w zależności od ich fazy rozwojowej, rodzaju gleby oraz wcześniejszego zapotrzebowania w wodę. ${ }^{40}$

36 Wyrok SN z dnia 24 lutego 1997 r., II CR 25/77, OSNiC 1978, nr 2, poz. 31.

37 Wyrok SN z dnia 20 stycznia 1970 r., II CR 623/69, Lex nr 1108.

38 K. Łyskawa, K. Rojewski, Kategorie zagrożeń i ryzyko w działalności rolniczej - szczególnie w produkcji rolnej, [w:] Ubezpieczenia produkcji roślinnej w Polsce, M. Kaczała, K. Rojewski (red.), Warszawa 2015, s. 55.

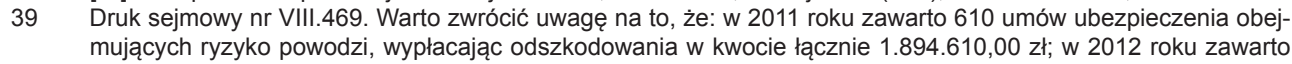
348 umów ubezpieczenia obejmujących ryzyko powodzi, wypłacając z tego tytułu odszkodowania w kwocie łącznie 1.081.410,00 zł; w 2013 roku zawarto 427 umów ubezpieczenia obejmujących ryzyko powodzi, wypłacając z tego tytułu odszkodowania w kwocie łącznie 1.697.745,00 zł; w 2014 roku zawarto 352 umowy ubezpieczenia obejmujące ryzyko powodzi, wypłacając z tego tytułu odszkodowania w kwocie 1.074.932,00 zł. 
Mimo że ustawodawca nie wskazuje na sposób wykazania przez rolnika wystąpienia suszy jako zdarzenia powodującego szkodę w ubezpieczonych uprawach, orzecznictwo przyjmuje, że dla ustalenia czy doszło do wypadku ubezpieczeniowego w rozumieniu art. 3 ust. 2 pkt 10 u.u.r. (na gruncie obligatoryjnego ubezpieczenia upraw) miarodajne są jedynie dane Instytutu Upraw, Nawożenia i Gleboznawstwa - Państwowego Instytutu Badawczego w Puławach. ${ }^{41}$ Co więcej, orzecznictwo często również odmawia w przedmiotowym zakresie mocy dowodowej innym środkom dowodowym, w tym również opiniom biegłych - wprost wskazuje się na niedopuszczalność zastąpienia danych z ww. Instytutu przez inne wnioski dowodowe. ${ }^{42}$ Takie stanowisko nawiązuje do norm kompetencyjnych ministra właściwego do spraw rolnictwa do określania w drodze rozporządzenia wartości klimatycznego bilansu wodnego dla poszczególnych gatunków roślin uprawnych i gleb z podziałem na województwa (art. 3 ust. 4 u.u.r.) oraz ogłaszania w drodze obwieszczenia wskaźników klimatycznego bilansu wodnego dla poszczególnych gatunków roślin uprawnych i gleb, z podziałem na województwa, na podstawie danych przekazanych przez Instytut Upraw, Nawożenia i Gleboznawstwa - Państwowy Instytut Badawczy (art. 3 ust. 5 u.u.r.).

Na marginesie jedynie należy zasygnalizować, że w przypadku ubezpieczeń dobrowolnych następować może wyłom od wskazanej powyżej w orzecznictwie zasady. Jak wskazuje Sąd Najwyższy, w sprawach o roszczenia z umowy dobrowolnego ubezpieczenia upraw rolnych wykazanie wystąpienia spadku klimatycznego bilansu wodnego poniżej jego wartości, określonej przez właściwego ministra, może nastąpić za pomocą wszystkich środków dowodowych. ${ }^{43}$ Wynika to bowiem z braku kształtowania przez ustawę o ubezpieczeniach upraw rolnych i zwierząt gospodarskich treści umów dobrowolnego ubezpieczenia upraw. Jeżeli zatem wynikające $\mathrm{z}$ art. 3 ust. 5 u.u.r. ograniczenia nie zostaną wprowadzone do dobrowolnego stosunku prawnego ubezpieczenia, wykazanie zaistnienia wypadku ubezpieczeniowego może nastąpić za pomocą dowolnych środków dowodowych.

Podobnie jak ma to miejsce w przypadku ryzyka powodzi, w ostatnich latach notyfikuje się spadającą liczbę umów ubezpieczenia upraw obejmujących szkody powstałe w następstwie ryzyka suszy. W 2008 roku (ostatni rok, w którym zanotowano wystąpienie przedmiotowego zjawiska w większych rozmiarach) zawarto łącznie 14.714 umów ubezpieczenia obejmujących ryzyko suszy, wypłacając z tego tytułu odszkodowania w kwocie łącznie 157.832.109,00 zł. Dla porównania,

\footnotetext{
41 Wyrok SN z dnia 26 listopada 2010 r., IV CSK 265/10, Lex nr 737286; wyrok SA w Gdańsku z dnia 26 lipca 2011 r., I ACa 691/11, Lex nr 1087207.

42 Ibidem

43 Wyrok z dnia 10 maja 2012 r., IV CSK 507/11, OSNC 2013, nr 1, poz. 10.
} 
w 2015 roku umów tych zawarto 90, a wypłacone z tego tytułu odszkodowania łącznie osiągnęły kwotę 182.490,00 zł. ${ }^{44}$

Pod pojęciem grad, jako ryzyko ubezpieczeniowe, art. 3 ust. 2 pkt 5 u.u.r. rozumie opady atmosferyczne składające się z bryłek lodu. Definicja ta jest tożsama z przyjętą w art. 67 ust. 2 pkt 6 u.u.o. w odniesieniu do obowiązkowego ubezpieczenia budynków wchodzących w skład gospodarstwa rolnego.

W piśmiennictwie wskazuje się, że grad jest zjawiskiem występującym lokalnie oraz na niewielkim obszarze, zwykle przynosząc szkody zawierające się w przedziale 5-20\% sumy ubezpieczenia, jednocześnie przy największym natężeniu w owocach, w okresach poprzedzających zbiory. ${ }^{45}$ Należy również zwrócić uwagę na utrzymujący się wysoki poziom umów ubezpieczenia obejmujących ryzyko gradu - najwyższy w stosunku do wszystkich ryzyk, o których mowa w art. 3 ust. 2 u.u.r. W 2015 roku zawarto łącznie 541.901 umów ubezpieczenia obejmujących to ryzyko, a w ostatnich 6 latach liczba ta nie przekraczała rokrocznie 169.000, kiedy to (w 2012 roku) była najniższa. ${ }^{46}$ Brak przy tym dostępnych informacji na temat odszkodowań, które z tego tytułu zostały wypłacone w poszczególnych latach. Statystycznie, ryzyko gradu łączone jest ze szkodami wyrządzonymi w związku z wystąpieniem huraganu, deszczu nawalnego, pioruna, obsunięcia się ziemi oraz z lawiną, a w 2015 roku z tego tytułu wypłacono odszkodowania na łączną kwotę 133.486.858,00 zł, co też stanowi największy udział w świadczeniach wypłacanych na podstawie wszystkich ryzyk, o których mowa w art. 3 ust. 2 u.u.r. (suma wszystkich wypłaconych w 2015 roku odszkodowań to 172.009.295,00 zł). ${ }^{47}$

Jak wynika z art. 3 ust. 2 pkt 11 u.u.r., pod pojęciem ujemne skutki przezimowania rozumie się uszczerbki spowodowane wymarznięciem (obumarcie roślin spowodowane działaniem niskiej temperatury powietrza), wymoknięciem (uszkodzenie upraw w wyniku działania zbyt dużej ilości wody, co dotyczy przede wszystkim roztopów), wyprzeniem (uszkodzenia w uprawach związane z niedostatecznym zaleganiem pokrywy śnieżnej ${ }^{48}$ ), wysmaleniem (wysuszenie upraw przez wiatr przy jednoczesnym działaniu ujemnych temperatur powietrza, uniemożliwiających przez

Druk sejmowy nr VIII.469. Warto zwrócić uwagę na to, że: w 2009 roku zawarto 9.001 umów ubezpieczenia obejmujących ryzyko suszy, wypłacając odszkodowania w kwocie łącznie 1.357.150,00 zł; w 2010 roku zawarto 1.494 umowy ubezpieczenia obejmujące ryzyko suszy, wypłacając odszkodowania w kwocie łącznie 604.312,00 zł; w 2011 roku zawarto 648 umów ubezpieczenia obejmujących ryzyko suszy, wypłacając odszkodowania w kwocie łącznie 2.313.371,00 zł; w 2012 roku zawarto 274 umowy ubezpieczenia obejmujące ryzyko suszy, wypłacając odszkodowania w kwocie łącznie 116.227,00 zł; w 2013 roku zawarto 117 umów ubezpieczenia obejmujących ryzyko suszy, wypłacając odszkodowania w kwocie łącznie 39.174,00 zł; w 2014 roku zawarto 85 umów ubezpieczenia obejmujących ryzyko suszy, wypłacając odszkodowania w kwocie łącznie 90.000,00 zł. K. Łyskawa, K. Rojewski, Kategorie zagrożeń, op. cit., s. 55-56. Jak wynika z druku sejmowego nr VIII.469, w 2010 zawarto 188.008 umów ubezpieczenia obejmujących ryzyko gradu, w 2011 roku było to 171.835 umów, w 2012 roku - 169.950 umów; w 2013 roku - 181.256 umów; w 2014 roku - 202.484 umowy.

Druk sejmowy nr VIII.469.

T. Kamiński, Likwidacja szkód w uprawach, [w:] Ubezpieczenia produkcji roślinnej w Polsce, M. Kaczała, K. Rojewski (red.), Warszawa 2015, s. 168. 
roślinę pobór wody ${ }^{49}$ ) lub wysadzeniem roślin (rozerwanie korzeni rośliny lub ich wydobycie na wierzch, powodowane zmianami objętości gleby w związku z zamarzaniem i rozmarzaniem zgromadzonej w niej wody ${ }^{50}$ ), w okresie od dnia 1 grudnia do dnia 30 kwietnia, skutkujące całkowitym lub częściowym zniszczeniem roślin, względnie całkowitą utratą plonu lub jego części.

W piśmiennictwie wskazuje się, że ujemne skutki przezimowania są drugim (obok suszy) najgroźniejszym zjawiskiem potencjalnie powodującym największe straty zarówno pod względem, ekonomicznym jak również ubezpieczeniowym. W 2012 roku, na terytorium RP na skutek wymarzania zniszczeniu uległo ok. 30\% roślin ozimych, a Ministerstwo Rolnictwa i Rozwoju Wsi oszacowało straty ok. 3 mld zt, ${ }^{51} \mathrm{z}$ czego jedynie $1 / 6$ została pokryta przez zakłady ubezpieczeń $\mathrm{w}$ związku $\mathrm{z}$ umowami ubezpieczenia upraw (wypłacono wówczas 587.776.226,00 zł odszkodowań z tego tytułu). ${ }^{52}$ Pod względem częstotliwości zawierania umów ubezpieczenia, ujemne skutki przezimowania są trzecim, po gradzie oraz przymrozkach wiosennych, najchętniej wybieranym przez rolników ryzykiem ubezpieczeniowym. ${ }^{53}$

Pod pojęciem przymrozki wiosenne art. 3 ust. 2 pkt 11a u.u.r. rozumie szkody spowodowane przez obniżenie się temperatury poniżej $0^{\circ} \mathrm{C}$, w okresie od dnia 15 kwietnia do dnia 30 czerwca, polegające na całkowitym lub częściowym zniszczeniu roślin lub całkowitej utracie plonu lub jego części. W praktyce, uszkodzenia spowodowane przymrozkami polegają na wykrzewianiu rośli, pękaniu pędów (ulegające zabliźnieniu), pękaniu głębokim lub płytkim oraz rozwarstwianiu łodyg. W późniejszych fazach rozwoju roślin przymrozki mogą natomiast prowadzić do uszkodzenia kwiatów, owoców, nasion lub innych części roślin stanowiących plon. ${ }^{54}$

Umowy ubezpieczenia w zakresie ryzyka przymrozków wiosennych cieszą się popularnością podobną do umów obejmujących ochronę od ujemnych skutków przezimowania (umów obejmujących to ryzyko notyfikuje się jednak wyraźnie więcej), ${ }^{55}$ jednakże w ostatnich latach wypłacone z tego tytułu odszkodowania są znacznie wyższe, stanowiąc istotną część wszystkich wypłacanych świadczeń ubezpieczeniowych (w 2015 roku odszkodowania te stanowiły ok. 17\% wypłaconych

51 K. Łyskawa, K. Rojewski, Kategorie zagrożeń, op. cit., s. 57.

52 Druk sejmowy nr VIII.469; analogicznie, w latach 2013-2015 było to: $13.033 .520,00$ zł; 10.695.829,00 zł oraz 8.810.421,00 zł.

53 Ibidem; w latach 2010-2015 od ryzyka ujemnych skutków przezimowania zawarto odpowiednio: 50.770; 54.204; 63.030; $65.620 ; 72.391$ oraz 372.172 umowy ubezpieczenia.

54 T. Kamiński, Likwidacja szkód..., op. cit., s. 171-172.

55 Druk sejmowy nr VIII.469; w latach 2010-2015 od ryzyka przymrozków wiosennych zawarto odpowiednio: $73.631 ; 69.896 ; 77.672 ; 75.063 ; 92.923$ oraz 393.923 umowy ubezpieczenia. 
świadczeń w ramach ubezpieczeń upraw; w 2014 roku odsetek ten przekroczył 50\% wszystkich wypłaconych odszkodowań). ${ }^{56}$

Odnosząc się do poszczególnych ryzyk ubezpieczeniowych, należy również zwrócić uwagę na okresy karencyjne przewidziane w art. 10c ust. 4 u.u.r., z nastaniem których (licząc od daty zawarcia umowy ubezpieczenia przymusowego) rozpoczyna się ochrona ubezpieczeniowa. W przypadku ubezpieczeń od ryzyka skutków powodzi, suszy, gradu i przymrozków wiosennych, odpowiedzialność zakładu ubezpieczeń rozpoczyna się po upływie 14 dni od daty zawarcia umowy ubezpieczenia (art. 10c ust. 4 pkt 2 u.u.r.). W przypadku natomiast ryzyka ujemnych skutków przezimowania, ochrona ubezpieczeniowa przysługuje od dnia zawarcia umowy ubezpieczenia, pod warunkiem jednak, że zawierana jest ona do dnia 1 grudnia danego roku (art. 10c ust. 4 pkt 3 u.u.r.). Ustawodawca nie rozstrzyga jednocześnie o tym, jak kształtować będzie się ochrona ubezpieczeniowa w zakresie ryzyka ujemnych skutków przezimowania, zawarta po 1 grudnia danego roku kalendarzowego. Postulować jednak należy ważność tego typu umowy (nieważność jako sankcja najdalej idąca musiałaby wynikać wprost z przepisów), a ocena zawartego stosunku prawnego ubezpieczenia powinna następować przede wszystkim w kontekście art. $806 \S 2$ k.c. traktującym o skutkach prawnych objęcia ubezpieczeniem okresu poprzedzającego zawarcie umowy ubezpieczenia. ${ }^{57}$ Analogicznie, początek odpowiedzialności w przypadku umowy zawartej po 1 grudnia będzie rozstrzygany na podstawie art. 814 k.c. ${ }^{58}$ Jednocześnie, wynikająca z art. $806 \S 2$ k.c. ewentualna bezskuteczność objęcia ochroną ubezpieczeniową okresu poprzedzającego zawarcie umowy ubezpieczenia, zdaniem autora, wpływa również na wywiązanie się przez rolnika z ustawowego obowiązku zawarcia umowy ubezpieczenia. Przepis art. 10c ust. 2 u.u.r. wspomina bowiem o objęciu upraw ochroną ubezpieczeniową, a nie tylko o zawarciu przez rolnika umowy ubezpieczenia.

\section{Podsumowanie}

Obligatoryjne ubezpieczenie upraw rolnych bez wątpienia stanowi narzędzie umożliwiające rolnikom dywersyfikację ryzyka prowadzonej działalności rolniczej, uzyskując w zamian za opłacenie składki (dotowanej przez Skarb Państwa) ochro-

\footnotetext{
$56 \quad$ Ibidem.

57 Zgodnie z powołanym przepisem, objęcie ubezpieczeniem okresu poprzedzającego zawarcie umowy jest bezskuteczne, jeżeli w chwili zawarcia umowy którakolwiek ze stron wiedziała lub przy zachowaniu należytej staranności mogła się dowiedzieć, że wypadek zaszedł lub że odpadła możliwość jego zajścia w tym okresie. 58 Zgodnie z powołaną normą, jeżeli nie umówiono się inaczej, odpowiedzialność ubezpieczyciela rozpoczyna się lub jej pierwszej raty (§ 1). Jeżeli natomiast ubezpieczyciel ponosi odpowiedzialność jeszcze przed zapłaceniem składki lub jej pierwszej raty, a składka lub jej pierwsza rata nie została zapłacona w terminie, ubezpieczyciel może wypowiedzieć umowę ze skutkiem natychmiastowym i żądać zapłaty składki za okres, przez który ponosił odpowiedzialność. W braku wypowiedzenia umowy wygasa ona z końcem okresu, za który przypadała niezapłacona składka (§ 2).
} 
nę ubezpieczeniową w zakresie określonym umową ubezpieczenia, od wskazanych w niej ryzyk ubezpieczeniowych. Służąc zapobieżeniu negatywnych dla gospodarki następstw zdarzeń losowych, stanowią jednocześnie ważny instrument zarządzania ryzykiem występującym w obszarze działalności rolniczej. Rodzimy porządek prawny posiada jednocześnie w tym zakresie doświadczenia, sięgające początków XX wieku (niemiecka ustawa z 1908 roku o umowie ubezpieczenia, obowiązująca na obszarze zaboru pruskiego, przewidywała m.in. dobrowolne ubezpieczenie upraw od gradobicia ${ }^{59}$ ) oraz okresu międzywojennego (w zakresie regulacji własnych). Aktualnie, od prawie 10 lat, przymus ubezpieczenia powiązany pozostaje z płatnościami bezpośrednimi uzyskiwanymi przez rolników w ramach systemu wsparcia bezpośredniego, stanowiąc następstwo udzielonych rolnikowi płatności.

Obowiązek ubezpieczeniowy obejmuje jednakże stosunkowo wąski zakres, odnosząc się do co najmniej 50\% upraw oraz co najmniej jednego ryzyka ubezpieczeniowego (wymienionego w art. 10c ust. 1 u.u.r.). Doświadczenia ostatnich lat wskazują przy tym na to, że rolnicy najchętniej wybierają umowy ubezpieczenia obejmujące jedno ryzyko ubezpieczeniowe, spełniając zatem minimum ustawowego obowiązku. Zagadnienie zarządzania ryzykiem, w kontekście pakietowych umów ubezpieczenia upraw, jak dotąd jest zagadnieniem marginalnym. Pozytywnie należy jednakże ocenić rosnącą liczbę ryzyk ubezpieczeniowych wynikających z sumarycznych porównań zawieranych umów ubezpieczenia. ${ }^{60} \mathrm{Za}$ wcześnie jednak, aby stwierdzić, czy stanowi to efekt regulacji Wspólnej Polityki Rolnej na lata 20142020 .

59 Z. Fendler, Prywatne prawo ubezpieczeniowe wraz z komentarzem i orzecznictwem sądów polskich, Kraków 1934 , s. 384 i n.

60 W 2015 roku zawarto umowy ubezpieczenia obejmujące łącznie 1.363 .990 ryzyk ubezpieczeniowych. W 2014 r. objęto łącznie 421.025 ryzyk, w 2013 r. - 361.615, w 2012 r. - 338.640; w 2011 r. - 321.768; w 2010 r. 339.004; w 2009 r. - 304.550; natomiast w 2008 r. (pierwszym po wprowadzeniu obowiązku ubezpieczeniowego) -328.997 . 


\section{ASSESSMENT OF INSURANCE RISKS \\ IN THE COMPULSORY CROP INSURANCE}

Keywords: compulsory insurance of crops, definitions of the insurance risks, agriculture

This article is an analysis of the issue insurance risks from the point of view of the subjective scope, and of the mandatory crop insurance in the Polish legal system. The issues raised as an element of introduced within the framework of the Common Agricultural Policy for the years 2014-2020 of the system of risk management in agriculture determine the direction of the development of crop insurance as a tool for securing not only the interests of agricultural producers, but also entities in any way dependent on the economic situation of agriculture as a sector of economy. At the same time, the author points to the issues specific to individual insurance risks, as well as to questions of interpretation arising under these regulations. The author also draws attention to the achievements of home insurance legislation in the matter, reaching the beginning of the reborn Polish State, as well as the development trends in the market of compulsory insurance of agricultural crops in Poland, from the perspective of its functioning after Poland's accession to the European Union.

\section{Bibliografia:}

Fendler Z., Prywatne prawo ubezpieczeniowe wraz z komentarzem i orzecznictwem sądów polskich, Kraków 1934.

Fuchs D., Zakres obowiązku prewencji w prawie ubezpieczeń gospodarczych. Uwagi na tle art. 826 k.c., „Prawo Asekuracyjne” 2004, nr 2.

Kamiński T., Likwidacja szkód w uprawach, [w:] Ubezpieczenia produkcji roślinnej w Polsce, M. Kaczała, K. Rojewski (red.), Warszawa 2015.

Kowalewski E., Prawo ubezpieczeń gospodarczych, Bydgoszcz - Toruń 2002.

Łyskawa K., Rojewski K., Kategorie zagrożeń i ryzyko w działalności rolniczej - szczególnie w produkcji rolnej, [w:] Ubezpieczenia produkcji roślinnej w Polsce, M. Kaczała, K. Rojewski (red.), Warszawa 2015.

Nawracała J., [w:] Prawo ubezpieczeń gospodarczych, Komentarz tom I, Z. Brodecki, M. Serwach, M. Glicz (red.), Warszawa 2010.

Orlicki M., Ubezpieczenia Obowiązkowe, Warszawa 2011.

Serwach M., [w:] Ryzyko ubezpieczeniowe, Wybrane zagadnienia teorii i praktyki, M. Serwach (red.), Łódź 2013.

Wąsiewicz A., Umowa ubezpieczenia, [w:] A. Wąsiewicz (red.), Ubezpieczenia w gospodarce rynkowej t. 3, Bydgoszcz 1997. 